\title{
Social History and Historical Sociology ${ }^{*}$
}

\author{
WOLFGANG KNÖBL**
}

\author{
Sociální historie a historická sociologie
}

\begin{abstract}
This paper deals with exchanges and misunderstandings between the German school of social history (most prominently represented by scholars from the University of Bielefeld (such as Hans-Ulrich Wehler) and Anglo-American trends in historical sociology (exemplified by the works of Barrington Moore, Theda Skocpol and Michael Mann). The social historians tended to dismiss historical sociology as too dependent on modernization theory, without taking into account the critique of that tradition by authors who brought processes of state formation and revolutionary change into the debate. On the other side, mainstream historical sociology worked with assumptions that limited its ability to change the terms and directions of sociological discourse, and to assimilate lessons from history. Among these inbuilt biases, organizational realism and materialism - particularly pronounced in the work of Michael Mann - stand out as particularly important. The paper closes with arguments in favour of bringing more history into historical sociology, with particular emphasis on three sets of problems. There is a need for more historical approaches to differentiation, less dependent on functionalist premises than the hitherto prevalent paradigm. A more explicit thematization of temporality in history and society would, among other things, help to clarify issues linked to the notion of path dependency. Finally, a reconsideration of the models and types of explanation in historical sociology would place more emphasis on their interpretive dimension.
\end{abstract}

Keywords: historical sociology, social history, modernization theory, differentiation, path dependency, explanation

"Although [Barrington Moore's Social Origins of Dictatorship and Democracy; W. K.] convincingly challenged the unreconstructed Marxist conception of industrial capitalism as the only decisive factor, and although its comparative perspective was certainly fascinating, the explanatory variable for political modernization was too narrowly conceptualized to be convincing for a longer time-period. This interpretation was finally discredited by the theoretically and empirically abstruse narrowing of Moore's approach in Theda Skocpol's States and Social Revolutions." These were the words used more than a decade ago by Hans-Ulrich Wehler [2000: 231, trans. W. K.], doyen of social history in Germany, in order to characterize the pioneering work of two central figures of modern Anglo-American historical sociology. And they made obvious - perhaps in a different way than intended by him - that the relationship between (German) social history and historical sociology was never a friendly one, but actually one full of misunderstandings.

Before coming back to that point, let me clarify the title of this essay and explain my intentions. Firstly, it is almost impossible to define social history or historical sociology as such. When I deal here with these two sub-disciplines, I must necessarily remain selective;

\footnotetext{
This text is based on a lecture given on the occasion of a meeting of the "Arbeitskreis moderne Sozialgeschichte" in Bochum, Germany, in April 2011.

** Wolfgang Knöbl, Institut für Sociologie, Georg-August-Universität Göttingen, Platz der Göttinger Sieben 3, 37073 Göttingen, Germany. E-mail: wknoebl@gwdg.de
} 
I simply cannot do justice to all representatives of these two rather broad historiographical and sociological currents. Secondly, the following discussion is biased insofar as I take the perspective of historical sociology and general sociology. So my view of social history is probably more critical than it would be if I had looked from the other side, namely from the perspective of social history. Having stated this, however, it should become quite obvious later on that praising general and historical sociology and bashing social history is not my aim. Thirdly, I do not intend to compete with Jürgen Osterhammel who several years ago published an enormously rich article which carries more or less the same title as my essay (2006). ${ }^{1}$ In this text, published in German, Osterhammel made many good points so that I can hardly find anything in his arguments that I would like to criticize, especially because in the fields of social history and historical sociology little has been published since then that would require a radical rewriting of Osterhammel's account. In order to pursue a somewhat independent reasoning I therefore must take a different road than the one chosen by Osterhammel.

This brings me to a short outline of the general direction of my essay. After having analyzed the difficulties that prevented early German social history from understanding the theoretically innovative aspects of historical sociology (I), I will focus on shortcomings and problems of historical sociology that have come to the fore in the last two decades and that have turned out to be rather similar to the ones social history had faced a couple of years earlier (II). Finally, I will discuss how current attempts to get out of these dead ends are to be judged, i.e. whether currently suggested theoretical moves are really promising (III).

\section{I.}

Wehler's reference to the works of Barrington Moore and Theda Skocpol, quoted above, will help me to structure the first part of my paper since it really highlights many of the hidden difficulties German social historians (but probably not only German ones) had in understanding the works of these two outstanding figures of Anglo-American historical sociology and their students. At the same time a focus on Moore's oeuvre will be the starting point of the second part of my paper, which will describe historical sociology's misunderstanding of its own project.

Wehler's claim that Moore's Social Origins was too narrowly conceptualized will not be addressed here although it is certainly interesting that - as Chris Lorenz has correctly pointed out [2004: 122] - Wehler himself, at least with respect to his book on the The German Empire, 1871-1918, used some of Moore's central theses to back his forceful defence of a German "Sonderweg” (exceptionalism) [Wehler 1985 (1973)]. But Wehler's quote is from the year 2000, The German Empire was written long before that, and in the meantime Wehler probably changed his theoretical position anyway. So it might really not be worth discussing this point here. It is more interesting to ask in which way German social historians in general referred to Barrington Moore and his oeuvre. And here at least three points are important insofar as they illuminate why the relationship between social history and historical sociology never was an entirely happy one - but also why the relationship of

1 The topic has already been tackled by a considerable number of interpreters, cf. Skocpol [1987] or Spohn [1989]. 
historical sociology to its own potentials and promises had become increasingly problematic (this will be discussed in the next section).

1. It is striking that even in the year 2000 Wehler, without much ado (but here he is not alone), labels Barrington Moore a kind of modernization theorist. Of course, Wehler refers to rather different types of "modernization theory", and he knows quite well the differences between Parsons, Bendix, Gerschenkron, North, and Moore. But he finds it altogether enormously difficult to imagine that anyone (apart from famous exceptions, of course) could be outside of the modernization paradigm at all, so that he even characterizes Marx as a representative of a "special kind of an optimistic, progressive, Eurocentric modernization theory" [Wehler 2000: 217]. Now, one simply cannot deny that glimpses of Enlightenment thought are to be found in many theoretical approaches of the social sciences; but this alone is certainly no justification for labelling all of them "modernization theories". Ignoring this fact had already led to paradoxical consequences in Wehler's own oeuvre: In one of his early theoretical books, in his Modernisierungstheorie und Geschichte (1975), modernization theory was at the same time devastatingly criticized and - if it could only be somehow revised - declared a useful paradigm [Wehler 1975]. This obviously has not changed since then! And that is the reason why Wehler cannot or will not see that historical sociology as developed by many students and admirers of Barrington Moore was basically a fundamental critique of modernization theory. While Seymour Martin Lipset, Reinhard Bendix, and Shmuel Eisenstadt, representatives of the later so-called "first wave"2 of historical sociology, actually saw themselves as somewhat heterodox modernization theorists - Lipset probably more than Bendix and especially Eisenstadt -, this is certainly not true with respect to Moore and his followers. They simply revolted against the historical amnesia of "grand theories". As Theda Skocpol put it, in their intellectual circle it had been all about massively reformulating "traditional macro-sociological ideas about the structures and processes of social change" [1987: 19ff.], which meant that one had to criticize Marxism, but also the "impersonal universals of functionalist modernization theory" [1987: 20]. ${ }^{3}$ In this respect it seems to me that Wehler's view of historical sociology was and is overly restricted since he failed and still fails to recognize its innovative momentum by subsuming far too much of it under modified versions of modernization theory.

2. Wehler certainly was not the only one who had enormous difficulties in understanding adequately the work of Barrington Moore; and here Moore's later works come into play. Symptomatic was the reception of his next major book, namely Injustice. The Social Bases of Obedience and Revolt published in 1978. Using mainly the example of the German working class in the period between 1848 and 1920, Moore raised the general question of what makes people revolt against existing social conditions. In his answer he particularly pointed to the phenomenon of "moral anger" / "moral outrage" and the "sense of injustice" and thus tried to focus on emotions in order to understand rebellions and revolutions [1978: 5]. There are many good reasons to criticize several of the arguments that Moore offered. And, indeed, critics quickly came to the fore to make their points. In retrospect, however, it is simply striking that social historians (although this also applies to the majority of

2 Here I do not strictly stick to the characterizations of so-called "waves" of historical sociologists as suggested by Adams - Clemens - Orloff [2005: 5ff.].

3 Cf. Calhoun [1987: 619f.], Hall [1989] and Abbott [1991: 203ff.]. With a somewhat different emphasis see Roth [1989: 417ff.]. 
historical sociologists!) completely ignored the decisive twist of Moore's book. In 1980, in a "Special Issue on Social History", the journal Theory and Society published several review essays on Moore's Injustice, including those of eminent (social) historians such as James J. Sheehan and Klaus Tenfelde. Tenfelde's fair and very positive review primarily focused on the question whether Moore's historical reconstruction of the behaviour of German workers is consistent at all; in a more theoretical fashion Tenfelde then criticized Moore for anthropologizing "too much, for assuming an unchanging human nature, and for marginalizing the social conditions of workers revolts resulting from the process of industrialization" [1980: 744]. The most innovative aspect of Moore's book, however, namely the topic of "moral outrage" and thus the relationship between morality, emotion, and action, is not really discussed. - James Sheehan, not a social historian in the classical sense, but an eminent representative of a sociologically informed historiography, not only ignored the potential of Moore's book, he even offered rather odd solutions to the problems Moore had raised. And, symptomatically, they went exactly in the opposite direction to the ones Moore had thought of: Sheehan criticized Moore for being silent on the topic of culture and of not being able to connect to the voluminous literature on "revolts", i.e. to the works of Chalmers Johnson, Charles Tilly, and Ted R. Gurr [Sheehan 1980: 729]. Sheehan's last point is rather grotesque insofar as at least Gurr's concept of "relative deprivation" has to do with everything but culture, and certainly not with any serious engagement with questions of morality and emotion! And it is also doubtful whether readers of Johnson or Tilly could have found anything which resembles ideas concerning those connections between morality and emotions Moore had in mind when writing the book. The reception of Moore's work, here illuminated by using the example of reviews by Tenfelde and Sheehan, indicates a significant reticence of early social history about questions that are outside the interpretative framework of rational action or of action along (class) interests. If I see it correctly, Moore's ideas were more welcome within social theory where at least from the 1990s onwards the concept of "recognition" had a huge impact [Honneth 1995: 167ff; cf. also Terpe 2009]. Social historians, in contrast, mostly ignored Moore; when they focussed on morals and phenomena such as honour at all (and this took place pretty late anyway), they rather looked to the works of E. P Thompson and Pierre Bourdieu [ $c f$. Grießinger 1981; Wirtz 1981; Frevert 1995]. But more on that later!

3. Also interesting is the reception of one of Moore's last major works, Privacy [1984], which carries the remarkable subtitle Studies in Social and Cultural History. As it was often noted, this is a strange book allowing many different readings, a book on the private sphere in classical Athens, in ancient Israel, and in the ancient Chinese empire during approximately the fourth century BC. I do not know whether this work published in 1984 was ever taken note of within social history; the period it covers was certainly not at the centre of interest of most social historians. Thus, my guess would be that the reception of Privacy within social history was not so different from the one within historical sociology: not really euphoric - to put it mildly! In retrospect, however, this is symptomatic because - and this would be my interpretation - Moore very early asked a question that quickly began to move into the focus not only of social theory [Joas 1996: 223-244] but also of conceptual history, namely the one of alternative forms of differentiation between different (value) spheres, among them the realm of the private and the public: It increasingly became clear that differentiation processes do not follow a kind of developmental 
logic; on the contrary, they are historically contingent and contested! And if so, then the results of such a contest are hardly to be known in advance and certainly not stable over time. Moore's early insight was rarely taken seriously within social history. Just think about Wehler's introduction [1987: 6ff.] to the first volume of his Deutsche Gesellschaftsgeschichte, where he - by recourse to a peculiar reading of Max Weber's writings and Jürgen Habermas's interpretation of them - claimed the seemingly self-evident form of differentiation between the spheres of the economy, politics (domination), and culture. In contrast to such an almost axiomatic proceeding, Moore's attempt to historicize forms of differentiation is extraordinarily instructive and innovative. And it is exactly this interesting step that should prevent both sociologists and historians from exclusively referring to Moore's Social Origins of Dictatorship and Democracy: There are simply more interesting arguments to be detected in Moore's oeuvre than just the ones he had offered in 1966 a point I will come back to soon.

Before that, however, more has to be said about another central figure within historical sociology: Theda Skocpol who - at least according to Wehler's interpretation - further narrowed the already too narrow approach of Barrington Moore.

Theda Skocpol's States and Social Revolutions [1979] was a comparative study of successful (and failed) social revolutions in France, Russia, China, Germany, Japan, and England which in the 1980s became one of the major starting points for the rapidly progressing institutionalization of historical sociology in the US and Great Britain. In fact, the central argument of this hugely influential study was probably irritating to almost all historians, even if especially social historians should have been capable of a more sympathetic reading. Skocpol, a student of Moore, in this book suggested a strictly structural-theoretical explanation of the events of, for example, 1789 in France or 1917 in Russia, so that real actors such as Robespierre or Lenin hardly played a role in her narrative. It was her explicit aim to demonstrate that an inter-state dynamic in particular imperial contexts led to uncontrollable developments and thus to social revolutions in France, Russia and China whereas (successful) revolutions in Germany, Japan, and England failed to materialize due to the fact that certain preconditions were missing there.

Wehler probably referred to this extreme structural determinism when he called Skocpol's approach "abstruse" as in the quotation cited above. And to be sure, for this very reason Skocpol's account has been heavily and justly criticized both by historians and historical sociologists. ${ }^{4}$ It is noteworthy, however, that Wehler does not at all want to acknowledge or to understand why, despite its weaknesses, this book became so important within historical sociology at all. And there is probably a reason for Wehler's stubbornness, because if he had taken Skocpol's insights seriously, many of the theoretical assumptions shared by him and the social historians would have been massively undermined. Four points seem worth mentioning here:

1. It was no coincidence that Skocpol in her explanatory model of social revolutions quoted more often Otto Hintze than Max Weber. The reason for this move is probably not difficult to understand: Weber, at least within American post-world war II-sociology and due to the enormous influence of Talcott Parsons and his students, has for a long time been seen as a sort of modernization theorist. Even today American sociologists sometimes

4 Cf. the exchange between Skocpol und Sewell, reprinted in Skocpol [1994a]. See also Hunt [1984]. 
characterize Weber in such a way, an interpretation supported by Hans-Ulrich Wehler. ${ }^{5}$ Hintze, however, is a figure hardly in danger of being associated with modernization theory. And this is exactly the reason why Skocpol, in her attempt to free herself of assumptions close to modernization theory, referred more to Hintze than to Weber. Since her explanatory model of social revolutions particularly emphasized the role of international entanglements and of wars, Hintze - at least at the time when Skocpol wrote her book was a less problematic source. Here one could make the very pointed argument that it was only in the aftermath of the Hintze reception within US-American sociology, so forcefully propagated by Skocpol, that Weber was discovered as a theorist of domination and power (Herrschaft) sociology [cf. Collins 1986]! It is irritating that this was apparently not seen by German social historians. Irritating because these very historians had always admired Hintze's comparative perspective on European history. No wonder, therefore, that Jürgen Kocka's [1972; 1981] essays on Hintze are among the best that have been written about this remarkable Prussian historian. However - and this is important - representatives of the Bielefeld school of social history always understood Hintze primarily as a theorist of bureaucracy [Page 1990] and less as an author who saw war and military conflict as central to the analysis of social processes. Precisely the latter, however, was particularly important to Skocpol and to historical sociology in general, and precisely this the German social historians didn't want to see. This leads directly to the next point.

2. Wehler obviously also overlooked that in using Hintzean arguments, Skocpol explicitly extended Moore's approach because Hintze's work served her well to emphasize the (so far neglected) role of the state and inter-state-violence in the development of modern societies. Referring to Hintze made it possible to leave the orbit of Marxian class theory that still played a huge role (although in a heterodox manner) ${ }^{6}$ even in Moore's Social Origins of Dictatorship and Democracy. Much of the "Bringing the State Back In"-movement [Evan, Rueschemeyer, Skocpol 1985] which since the 1980s heavily influenced macro-sociology in the US and Great Britain, was based on Skocpol's (and Hintze's) work; this was of course a movement, which not only rebelled against Marxist class theory but also against "bourgeois" modernization theory. Authors within this movement tried to demonstrate the autonomy of the state by pointing to the (often warlike) logic of the international state system which guaranteed state actors at least some autonomy. By bringing interstate violence back in, however, these authors automatically also criticized the assumption that there is a somehow smooth and peaceful pattern of societal development, that societal development is something that could be analyzed without taking into consideration the conflict-ridden (extra-societal) character of state-systems and its often devastating consequences.

3. The intense focus on foreign policy in general and military matters in particular also made it clear that historical sociology was not really interested in "Sonderweg"-debates

\footnotetext{
5 It is remarkable that both modernization theorists and postcolonials label Weber in the same way - although the label "modernization theorist" then has opposite normative connotations. In this context one should perhaps ask whether this has more to do with Weber's oeuvre or with the current struggle for distinction within the social sciences. That Weber has become a kind of persona non grata within postcolonial studies can certainly not exclusively be explained by Weber's arguments but by the fact that modernization theorists always have used Weber as a reference point and thus came under fire from a theory that from its very beginnings has been rather critical of assumptions so dear to modernization theory.

6 Cf. Skocpol's early criticism of her teacher reprinted in Skocpol [1994b (1973)].
} 
(debates on national exceptionalisms), especially not in discussions of the German "Sonderweg". Relevant authors in this sub-discipline found it more interesting to analyze the violent origins of basically all Western societies, a focus that was obviously not in the centre of early social history. ${ }^{7}$

4. Wehler also overlooked or did not want to see that stressing the importance of military and foreign policy matters also heavily undermined the concept of (an isolated) "society", something so dear to historians from Bielefeld ("Gesellschaftsgeschichte"!). Whereas in the mid-1980s neither German social history nor German sociology (apart from the works of Friedrich Tenbruck [1981 and 1994]) ${ }^{8}$ attempted a systematic critique of the concept of society, authors who followed Skocpol's pioneering work [Skocpol 1987: 23] - particularly Anthony Giddens [1985] and Michael Mann [1986; 1993; 2012] in Great Britain - at that time tried hard to get rid of this term. Since these authors argued that distinct and isolated macro-entities such as those "national societies" hardly ever existed, they also distanced themselves from any idea of an endogenous "social evolution", 9 a way of thinking rather popular in at least some accounts influenced by modernization theory. If it is true that - as William H. Sewell [2005: 325] claims with reference to Keith Baker since the Enlightenment the problem of social order has been addressed via the concept of society and not via religion any longer; then, if it is obvious that the concept of "society" was invented in a peculiar historical context, it is amazing how little effort social historians have made in order to historicize this concept.

Summarizing especially these last four points, one has to state that the reception of historical sociology by German social history was indeed problematic insofar as especially historical sociology's innovative aspects were simply not seen. However - and this points to the second part of this paper - Skocpol's theoretical arguments and the ones used by many of her students or followers (the paradigmatic core of the sometimes so-called "second wave" of historical sociology), soon turned out to be problematic as well and this in a way which, strangely enough, was similar to the situation within social history.

II.

It was above all Skocpol's States and Social Revolutions which in the late 1970s and early 1980s became the starting point for the formation of the - here one could loosely use the language of Thomas S. Kuhn - paradigmatic core of the new historical sociology (the sometimes so-called "second wave"), a current in which (next to Skocpol) especially American and British authors such as Charles Tilly, Dietrich Rueschemeyer, Peter Evans, Randall Collins, Jack Goldstone, James Mahoney and Anthony Giddens (at least for a short time), John A. Hall, Michael Mann occupied central positions. If one wants to characterize this core with bold strokes and without fear of simplifications, one could argue that the

7 See Ziemann [2003: 22f.]. Within German sociology this was hardly ever recognized - with exceptions, however: See above all Joas [2003].

8 In France a differently motivated critique was articulated by Touraine [1981].

9 Here one would have to distinguish between different theoretical concepts of social change; whereas Giddens' criticism of any form of evolutionism was certainly to be called radical insofar as he saw only "episodical history" as theoretically valid [cf. Giddens 1984: 227-280], Mann assumed a kind of continuous development and drift of the sources of power, even though that had nothing to do with societal evolution. 
mostly comparative works of these authors usually thematized the relationship between states and capitalism, a rather broad focus that was developed through studies of seven clearly recognizable thematic topics: a) the formation of social classes and the resulting change of forms of protest, particularly in Europe and in the U.S. [Tilly, Tilly, Tilly 1975; Tilly 1986], b) the variety of state formation in these parts of the world, ${ }^{10} \mathrm{c}$ ) the emergence of peculiar types of welfare states in the Western world, ${ }^{11} \mathrm{~d}$ ) the conditions of the emergence of democracy and parliamentarianism [Rueschemeyer, Huber Stephens, Stephens 1992; Downing 1992; Ertman 1997; Collier 1999], e) the causes and structure of social revolutions, ${ }^{12} \mathrm{f}$ ) the relationship between states and imperial structures on the one side and economic development on the other [Evans 1995; Davis 2004; Lange, Rueschemeyer 2005; Lange 2009; Mahoney 2010], and g) the so-called Rise of the West [Hall 1985; Mann 1986].

Analyzing the theoretical structure of these studies one could claim that they all are based on assumptions close to something that might be called "organizational realism and materialism". 13 Theoretical arguments used were "organisationally realistic" because it was taken for granted that identifiable collective entities (such as social classes, states etc.) simply do exist. These social units were then analyzed in their mutual interactions in order to create typologies of constellations that would allow the formulation of rather general statements concerning the direction of processes of social change. But the theoretical arguments used could also be called "organisationally materialistic" because entities like classes or states were primarily analyzed with respect to their organizational structure since it was assumed that it is the structure and resources of these entities that matter, that structures and resources determine the way collective units act. This point is certainly similar to the one at the centre of the debate between cultural and social historians and it is probably fair to say that historical sociologists of this "second wave" basically argued in line with social historians: they too were not really interested in cultural processes that define the boundaries of social entities. Taken for granted was their stability, not their fluidity, because otherwise the belief in the self-evident existence of such entities and thus their usability with respect to model-building could have been questioned.

Such a theoretically justified "organizational realism and materialism" probably became so dear to historical sociology for methodological reasons as well. In this context one must not forget that Skocpol's States and Social Revolutions had also triggered a huge debate on the peculiarities of the comparative method: Referring to John Stuart Mill's remarks on the "method of difference" and the "method of agreement", Skocpol had quite explicitly made systematic and perhaps even formalized comparisons the hallmark of historical sociology. Doing so, some theoretical assumptions were already self-evident: If a comparative design

${ }^{10}$ Next to the studies by Michael Mann the following works have to be mentioned: Skowronek [1982], Gourevitch [1986], Kohli [1987], Tilly [1990], Bensel [1990], Downing [1992], Ikegami [1995], Ertman [1997], Mahoney [2001], Centeno [2002], Barkey [2008].

11 Hall [1986], Baldwin [1990], Esping-Andersen [1990], Skocpol [1992], Orloff [1993], Pierson [1994], Hicks [1999]. Cf. the essay by Amenta [2003].

12 Tilly [1978], Goldstone [1991], Paige [1997], Parsa [2000], Goodwin [2001]. For an overview see Goldstone [2003].

13 Here I obviously refer to Tilly's and Skocpol's term "organizational realism”. This term defines an approach which has as its central premise "that the real units of research are not just simple aggregates of individuals, on the one hand, or reified totalities like 'societies' or 'social systems', on the other. Rather, social relationships are the key objects of research, as embodied in networks, communities, associations, or large-scale complex organizations." (cf. Skocpol [1987: 25/26]). 
aims to eliminate potential causal factors by pointing to differences and similarities in the cases compared, then one implicitly has to accept that these factors are indeed discrete and rather stable units in all the cases investigated. If this is so, then the task of the researcher is not primarily to analyze what a state, a social class etc. is or could be in the minds of social actors. ${ }^{14}$ It is the investigator alone who defines certain variables, i.e. s/he is the one who claims that a state is weak or strong, that a labour movement is either radical or reformist, that a national economy is more defined by the predominance of its industrial sector or the dominance of large estates etc. Loosely formulated it could be said that historical sociologists of this "second wave" discussed the existence/non-existence of variables rather than their historical and cultural context. Thus the objects of comparative studies were already prefigured by the method of systematic comparison so intensely used within historical sociology. I shall come back to the problems associated with such an approach a little later, but first let's have a brief evaluation of the theoretical and methodological achievements of this "second wave" of historical sociology. Three points seem to me particularly worth highlighting here:

1. There can be no doubt that in the aftermath of Skocpol's book on States and Social Revolutions comparative methods were more seriously discussed than ever before. The niveau of reflexivity has never been higher - just look at the technically highly sophisticated work of Charles Ragin [1987; 2000]. And as an aside: Because social historians have quickly caught up with historical sociologists and because they have also dealt extensively with questions of cultural transfer [Kaelble/Schriewer 2003] (a problem difficult to handle in a comparative design), there seems to be not much left of a methodological difference between social history and this "second wave" of historical sociology.

2. Undoubtedly to be praised are the achievements in connection with research on the state. The initially rather loose talk of the "autonomy of the state" is no longer en vogue since in the meantime, for example, Michael Mann's distinction between the despotic and infrastructural power of the state has been demonstrated as being extremely fruitful [Soifer 2008; Soifer/vom Hau 2008]. State administrations are now among the best analyzed themes of historical sociology. And it should be noted that historical sociologists didn't shy away from searching for the roots of modern states even in the days of medieval Europe. The picture of political "modernity" (if one wants to use that term) drawn by historical sociologists has little in common with the nice one painted by classical modernization theory some decades ago since historical sociologists very much - and for good reasons - emphasized the violence-prone character of state-induced processes. And Mann's comments on the peculiarities of infrastructural power certainly have had - albeit in a transformed form - an at least indirect impact on German social history too if one just thinks of the work of Dirk van Laak [2001; 2004; 2008].

3. The dissolution of the concept of "society" so forcefully promoted by Michael Mann and others has been widely accepted within historical sociology; it is now more or less common sense that the nation-state of the long 19th and early 20th century had a unique morphology; therefore it is simply not plausible any longer to regard the shape of its "society" typical for macro-units per se. Criticism of the concept of "society" has also been accepted relatively quickly because by doing so it was possible to challenge the

14 An early attempt in this direction is to be found within French sociology, cf. Boltanski [1982]. 
often unsubstantiated talk of "globalization" and/or "global society". Drawing on Michael Mann's distinction between different sources of social power [cf., for example, Weiss 1998] allowed to ask questions such as: Are cultural networks really as global as political ones, economic networks as far-reaching as military ones? And above all, do all four sources of social power have the same effect on social change?

Besides these (in my view) indisputable gains that have resulted from the theoretical and methodological approach of historical sociology's "second wave", the losses should not be ignored, however - losses highlighted at an early stage by at least some authors who somehow have always stood at the edge of this paradigmatic core of historical sociology (such as William H. Sewell, Craig Calhoun, and Andrew Abbott ${ }^{15}$ ). Since these losses (and problems) resemble those of (German) social history, I will deal with them at some length. Based on this discussion I will then use somewhat different arguments than the ones brought forward by social historians (such as Thomas Welskopp or Benjamin Ziemann) in order to criticize their own sub-discipline.

1. Already in 1996 Craig Calhoun pointed out that historical sociology's focus on the comparative method has led to a neglect of more substantive and thematic issues. Historical sociology - sitting on the fence between history and sociology - has tried to improve its standing within general sociology by above all demonstrating its methodological skills. As a consequence, as Calhoun [1996: 327] claims in a convincing but also somewhat vague manner, substantial "matters of culture and meaningful social action" had been more or less neglected. I believe one should argue more precisely here, especially since one can build upon my previous remarks on the consequences of the use of the comparative method: Historical sociology's "organizational materialism" with its focus on structures and resources also meant that it was above all and often exclusively interested in examining how actors (in organizing social movements, in running the state apparatus, etc.) most appropriately and rationally used the resources available to them in order to achieve their goals. A purposive-rational model of action dominated because historical sociologists primarily interpreted the constellations between different collective actors as a struggle of (rational) interests. It was not so much about cultural content, it was not about world views, it was not about different definitions of the situation by different actors, and it was not about emotions of actors in these very situations (just think here again of Moore's widely misunderstood book on Injustice!): Far more weight was given to the resource-based agency and penetrating power of organizations. ${ }^{16}$ The mainstream stance was - as underlined most recently by Dietrich Rueschemeyer [2009: 38$]^{17}$ - an at best extended rational choice

${ }^{15}$ Adams, Clemens, Orloff [2005a: 7] - in addition to Abbott - also name authors such as Charles Camic, David Zaret and Viviana Zelizer.

16 This also means that similarities with "classical" social history are easy to identify; Wehler in his attempt to conceptualize cultures is obviously not really interested in interpretative schemes and belief systems and has a much stronger focus on cultural institutions [cf. Lenger 2010: 123ff].

${ }^{17}$ Even though various authors within historical sociology use different models of actions, it is certainly possible to argue that a kind of affinity to the rational choice-approach can be detected in Tilly, Skocpol and Mann: "Human beings are restless, purposive, and rational, striving to increase their enjoyment of the good things of life and capable of choosing and pursuing appropriate means for doing so" [Mann 1986: 4]. When Mann, for example, talks about ideological or cultural sources of power, he is not primarily interested in cultural content per se but in the way how (and via which logistical means) actors maintain and propagate ideologies. This is quite similar to the way how Mann also deals with economic, military, and political sources of power. Here he also asks which choices human beings make when they act. And his answer is always strictly "rationalistic": 
approach, an approach that seemed especially plausible because a supposedly universal model of action allowed to stick to the aim of formulating general statements.

2. In contrast to German social history, which since the 1980s has apparently lost interest in analyzing revolutions [Osterhammel 2006: 94], the "second wave" of historical sociology as promoted by Skocpol and others, has enormously enlarged our knowledge about revolutionary outcomes. So much work has been done on revolutions that it is probably not wrong to claim that no other topic has been more systematically researched within historical sociology. I do emphasize this because the early focus on "revolutions" would have offered the opportunity to study the phenomenon of temporality in a systematic way, would have allowed to reflect on different types of processes and their temporal forms. If one looks at this research on revolutions, however, one quickly realizes that this has hardly ever been done. In an early Trotskyist critique of States and Social Revolutions Michael Burawoy with some justification accused Skocpol of "freezing history" [Burawoy 1989: 769] through the use of Mill's comparative method. How can we make reasonable comparisons at all - so Burawoy asked - when, by using the systematic application of a method, we are dealing with explanatory variables that never are analyzed in their temporal setting and when we are discussing explananda (revolutions) in a way that almost negates the possibility that they might have influenced each other? Andrew Abbott [1991: 227] - coming from a completely different direction - has made this point as well: “(...) events (...) are not single properties, or simple things, but complex conjunctures in which complex actors encounter complex structures. On this argument, there is never any level at which things are standing still. All is historical. Furthermore, there are no independent causes. Since no cause ever acts except in complex conjuncture with others, it is chimerical to imagine the world in terms of independent causal properties acting in and through independent cases." Abbott concluded that this historicity of processes can only be represented in a narrative way which makes systematic comparisons - and here he explicitly included in his critique Charles Ragin's brilliant work - problematic [1991: 229].

3. In an instructive and self-critical essay (which, however, is more convincing in its diagnosis of the problem than in its solution), the German social historian Benjamin Ziemann pointed out that his discipline, as practiced in Germany, has neglected many interesting topics such as environmental history, women's history, the history of consumption, the history of war and violence, etc. [Ziemann 2003: 19ff.]. This reflects a commitment

Criticizing neo-realist theory within the discipline of International Relations, for example, Mann questions the rationality of decisions made by state-actors. But he is not doing so in order to point to the irrationality of these actors or to the culture-boundedness of their decisions. On the contrary, he is convinced that - due to polymorphous state structures and thus the complexity of the conditions of action - interaction processes in this field almost automatically lead to irrational or at least unintended consequences. To say it in the language of economic theory: Mann reckons with the "bounded rationality" (Herbert Simon) of actors, not with the fact that different actors might have different concepts of rationality, not with the fact that within the field of international relations actors could have different imaginations of national power and grandeur. Mann obviously believes that he can stick to such a narrow theory of rationality since he also assumes that the organizational power of ideology has decreased in the 19th and 20th Century. Such a claim, however, can be criticized for good reasons [cf. Gorski 2006: 118ff.], because, for example, Christianity achieved its largest extension not before the 19th century and because secular religions such as nationalism and Marxism can hardly be made congruent with Mann's thesis. Mann [2006: 345] has at least partially accepted this critique, something which should have consequences, of course, with respect to his thesis of differentiation between ideological, economic, military, and political sources of power. 
to the production paradigm, also expressed in rather careless talk of "industrial society" and a concomitant focus especially on the world of wage labour, on social inequality on the business firm etc.).Hans-Ulrich Wehler and Thomas Welskopp, as representatives of an older and younger generation of social historians, have also admitted and criticized these thematic shortcomings [Wehler 2010 (1988): 436; Welskopp 1999: 218]. Interestingly a very similar neglect of such issues - with the exception of war, of course - can be found within historical sociology. One could argue, in an analogous way to Ziemann's point, that the strong focus of historical sociology on the state has also caused many biases and theoretical reductions - and presumably such a claim would not be entirely wrong. I would like to make a somewhat different argument, however. In my view it is not the thematization of the state itself that has led to such reductions and biases (research topics indeed can always be expanded, complemented, etc.), but rather the application of theoretical instruments (this aforementioned "organizational realism and materialism") within a framework characterized by assumptions close to the theory of social differentiation. To make this point as explicit as possible: Wehler's distinction between economy, politics (domination), and culture is in terms of differentiation theory not so far away - with some significant divergences, of course - from Michael Mann's attempt to distinguish between ideological, economic, political, and military power sources and networks. Even if Mann uses this language of differentiation in one way and Wehler in another, neither of them wastes time in thinking through how and where these distinctions between societal spheres (or power sources) have come into being, whether they simply can be assumed as self-evident especially when one compares countries, states, cultures, etc. Barrington Moore's point in Privacy, namely to examine the historically variable genesis of forms of differentiation, has never been taken too seriously within this "second wave" of historical sociology. No wonder, therefore, that although, for example, Theda Skocpol in her impressive study on the origins of the American welfare state (Protecting Soldiers and Mothers) enormously emphasized the role of women's movements, her perspective on these movements was above all an organizational one: She basically looked at interests and resources within organizations. The more fundamental question, however, namely how and why peculiar forms of differentiation between, for instance, the private and the public emerged at all, so that feminists and social policy makers could only operate and organize themselves successfully within already drawn boundaries, was hardly ever asked. Thus Skocpol's book was at least partly based on assumptions concerning processes of differentiation that were not further analyzed. Or - to take another example: Philip S. Gorski [2003] was one of the few historical sociologists who at a very early date seriously dealt with the topic of religion, in his case with the relationship between religion and state formation in Prussia and the Netherlands. Within Gorski's overall convincing book, however, it seems to be self-evident most of the time what religion and what the political sphere really is. But could one not take a rather different perspective and ask - by following insights of Talal Asad [2003] - why social and political movements and groups were able at all to impose their particular view of the "secular" and the "religious" and the boundaries between them? Asad's thesis indeed rests on the insight that concepts like secularism or religion/religiousity have no fixed content at all but have always been negotiated in specific historical contexts - a point until recently widely neglected in the historical-sociological literature [see, however, Starrett 2010; Agrama 2010]. Would it not be an entirely different perspective to the one preferred by 
the "second wave" of historical sociologists, if we were to ask who was able to sucessfully use labels like the "secular" or the "religious"? Such questions, however, would certainly undermine any attempt to build general models of the interaction between seemingly objective factors like "religion" and "state" in order to explain certain outcomes. Thus, my argument would be that quite a few of the biases and thematic deficits within historical sociology's "second wave" are to be explained by its unquestioned recourse to theories of differentiation - a point that may also apply to social history. ${ }^{18}$

Historical sociology in the late 1970s and 1980s began as an attempt to counter the "grand theories", with their often speculative and empirically often unsound models; but, of course, practitioners of historical sociology also had the expectation that the empirical work they were engaged in would create generalized statements, i.e. that one could categorize robust macro processes and then, with the models obtained, influence the theoretical discourse within the discipline of sociology as a whole. It turned out, however, that the original optimism was not justified, something which was quickly spelt out within the well-established research on social revolutions. Of course, Skocpol's arguments in her 1979 book remained in the centre of the discussion and thus were constantly criticized, refined, and transformed. But that was not the problem! Rather more problematic was that again and again new cases popped up - from Iran to Nicaragua - for which Skocpol's explanatory model was hardly plausible: 19 This was so, because in these cases factors like pressures from the international state-system were not visible or at least only present in a different way or because suddenly new (collective) actors emerged, such as the clergy and students who were not important at all in Skocpol's model. The consequence of these debates was that a general theory of revolutions (and macro-processes) was further away than ever, as was demonstrated by Jack Goldstone in an article published in 2003 that summarizes 25 years of research on revolutions: Here he had to admit that it was almost impossible to make general statements about causes of revolutions, simply because the interaction effects between factors or variables could barely be controlled [2003: 76ff]. According to him it is at best possible to provide some minimal conditions for successful (social) revolutions. These conditions, however, turn out to be rather trivial so that Goldstone's convincing and elegant overview of the state of research on social revolutions ends somewhat disappointingly. To paraphrase Goldstone's conclusion:"Yes, there was undoubtedly a growth of knowledge, but unfortunately only one which made aware of the complexity of such processes, less one which led to general theories"! This was probably one of the reasons why at least some representatives of a younger generation of historical sociologists decided - here perhaps comparable to the distanciation of cultural historians from the field of social history - to make a U-turn, as can be seen in the anthology by Julia Adams, Elisabeth S. Clemens, and Ann Shola Orloff entitled Remaking Modernity. Politics, History, and Sociology [2005]. Since then one could indeed detect a kind of a "third wave" of historical sociology.

However, although many essays are undoubtedly well-written and highly interesting, I have some doubts whether social historians will be able to draw a lot of (theoretical)

18 Thus it is not convincing to me when Benjamin Ziemann suggests that we should draw upon Luhmann's oeuvre and especially on his theory of differentiation in order to solve the problems of social history.

19 Here one should immediately add, however, that Skocpol herself had always explicitly claimed that her model of "social revolutions" is not one that should be generalized! 
inspiration from this volume - partly because the contributors mainly focused on three rather familiar aspects. Firstly, the editors and most of the authors criticize the suppression of certain topics within traditional historical sociology ("religion, emotion, habit, the arational core of war and state violence", Adams, Clemens, Orloff [2005a: 23]) and the fact that it maintained somehow the old dualisms so prominent within modernization theory, although this aspect is not specified in detail [2005a: 21ff.]. It only seems to be clear, that at least some of these problems have to do with the widely used method of systematic comparison [2005a: 8]. Second, as pointed out by the editors themselves in their introduction and as readers of the other essays in this volume will quickly learn, it is anything but easy to circumscribe and define this so-called "third wave" of historical sociology. Of course, they all would like to distance themselves from their predecessors. But apart from this, can one still find a kind of paradigmatic core of historical sociology and, if so, what might it look like? Some of the contributors have positively referred to the theory of Pierre Bourdieu as a kind of vanishing point of the volume (at least this is the way how Abbott [2006: 346] sees it), but certainly not all ${ }^{20}$ so that the problem of coherence is undoubtedly there. Third, the editors themselves point to the danger that too strong a focus on culture and action in this "third wave" might push the necessary analysis of institutions into the background so that the weaknesses of the "second wave" of historical sociology would be reproduced in a kind of mirror image. - All three points addressed in that volume are still on the agenda of Anglo-Saxon historical sociology. But it is clear - to repeat it once again - that they had, much earlier, been addressed in a similar way in discussions about the status of social history. "Nothing New on the Western Front"! Is that perhaps the sobering diagnosis? Not quite so! At least a few points seem theoretically noteworthy, aspects which are indeed the constructive result of the preceeding comparison between the development of social history and historical sociology. This brings me to the last part of my paper where I will first ask which theoretical moves might be promising within social history, seen against the background of related current debates within historical sociology (A). Having done that, I will deal with the problem of the temporality of events as central to both sub-disciplines (B) before finally saying a few words about the problem of explanation within social history and historical sociology $(\mathrm{C})$.

\section{III.}

(A) Social historians themselves have made many suggestions in order to remedy shortages and deficits and to counteract theoretical and methodological biases prevalent in their subdiscipline. Three of these proposals should be scrutinized on the background of recent debates in historical and general sociology.

In Wehler's more recent texts and in the works of other social historians, we can detect a significant attempt to solve the problem of shortcomings in the understanding of culture by incorporating the theory of Pierre Bourdieu. This is a possible move, of course, and proponents of such a proposal might hope that they will have the same success as followers of Bourdieu enjoy right now within sociology. However, in this context one should recall at least two points. Firstly, Bourdieu's theory of social fields has been justly criticized for

${ }^{20}$ It is certainly not true with respect to Biernacki [2005]. 
being based on a model of purposive-rational action, so that questions at the heart of, for instance, Barrington Moore's Injustice can hardly be answered ("moral outrage"!). One can, of course, speak of "moral capital" as has been done by Michèle Lamont in order to balance the one-sidedness of Bourdieu's theory and to cure his blindness with respect to moral issues. However, it seems questionable whether the mere emphasis on the drawing of moral boundaries really grasps all those aspects normally addressed when we deal with questions of morality. This becomes obvious if one contrasts Lamont's Money, Morals \& Manner [1992] with, for example, Viviana A. Zelizer's The Social Meaning of Money [1994]: Zelizer provides an enormously rich phenomenological description of the processes of moral attribution to an abstract and impersonal entity such as money, processes that hardly could be understood by just using Lamont's central Bourdieusian argument that by invoking morals social actors basically are drawing social boundaries. Looking back at the development of social history one might ask whether the plausibility of the recourse especially to Bourdieu's theory - to be seen in studies by, for instance, Andreas Grießinger in the 1980s and Ute Frevert in the early 1990s (see p. 12 above) - was due to the fact that, by using Bourdieu's theory in order to focus on phenomena such as honor, one could still stick to the purposive-rational model of action and to a concept of (socio-economic) "interests" that has always been at the heart of social history, even before the so-called cultural turn. - Secondly, from the perspective of sociology it is simply odd to witness a historian's love affair with a theorist whose contribution to a theory of social change was rather limited and who certainly - due to the whole design of his theory - always had enormous difficulties in theorizing social change apart from shifts within certain social and cultural fields caused by the continuous struggle for distinction. ${ }^{21}$ In this context one should emphasize that prominent authors who have been and still are rather marginal to the "second wave" of historical sociology (next to Sewell one might refer to, for example, Richard Biernacki or Andrew Abbott) are highly critical of Bourdieu, exactly because the analysis of different types of processes, an aim once seen as the central task of historical sociology, is certainly not facilitated by a recourse to Bourdieus's theory [Biernacki 2005: 90; Abbott 2006: 346].22

From the field of social history came another proposal as well, one made by Benjamin Ziemann who argued that in order to overcome the limits of the production paradigm one should use building blocks of Luhmann's systems theory. I'm not sure if this last step will be particularly fruitful. For although it may well be that the "old" social history - as claimed by Ziemann - was built without any further reflection on the concept of 'industrial society" (see p. 20 above) [2003: 23ff.], I have my doubts whether the concept of "functional differentiation" and the Luhmannian talk of a "world society" emerged in a more reflexive context. Right now the most fruitful studies currently using these terms are those which are interested in empirically investigating phenomena of differentiation and not

${ }^{21}$ This was the criticism of Sewell [2005: 139].

22 Attempts have been made to reform the conceptual framework of historical sociology convincing with the help of Bourdieu's theory. On the whole, I do not find them convincing; see the somewhat disappointing anthology by Steinmetz [1999]. - One should add here that in the last decades the Bourdieu school in France has been weakened; some prominent students of Bourdieu tried to escape the orbit of their master with the argument that Bourdieu's whole theoretical edifice has led to a problematic neglect of the situation and the agency of actors therein, cf., for example, Boltanski [2010: 38ff]. 
those that assume the undeniable existence of functional differentiation..$^{23}$ This also means that the theoretical edifice of a "world society" which, at least in Luhmann's theory, owes its existence to a purely logical conclusion from the premise of geographically unbounded functional systems, stands on shakier grounds than is often assumed.

From the fields of cultural [see Daniel 2010 (1993): 409] and social history [see Welskopp 1998: 179] came, at the same time, the call for a stronger focus on action theory. In this respect Anthony Giddens' structuration theory was highly recommended - to my mind a plausible proposal not only because a recourse to Giddens allows the necessary critique of the concept of "society," but also because Giddens' action-theoretical approach avoids this strange dichotomy between the social and the cultural, between social and cultural history. The recourse to Giddens, as recommended by Daniel and Welskopp, occurs only in a rather restricted way, however, and this brings me to my next major point.

(B) In his major theoretical work, The Constitution of Society, Giddens sharply criticized the many overt and covert evolutionist assumptions within sociology. If I see it correctly, the plea for an "episodic history" to be found in this work has rarely been positively acknowledged, perhaps because the statements there were very short and also anything but clear [1984: 244 ff.]. But, in fact, Giddens' emphasis on world-historical linkages ("world time"), on contingent developmental trends and sudden breaks within developmental paths, on the difficulties of historical explanation in the face of such complexities and contingencies etc., was according to my opinion and despite some weaknesses in the argument, quite forward-looking. This can be seen if one reviews current debates within historical sociology. They suggest that many of the traditional concepts (those inherited from the sociological founding fathers), created in order to grasp supposedly long-term historical processes, are now hardly considered viable. This impression was already characteristic of the "second wave" and even stronger in the "third wave" of historical sociology. The concept of secularization came under heavy fire, "individualization" is defined rather differently in different national sociologies, and it is still unclear what sociologists exactly mean when they talk about processes of "industrialization,",24 "bureaucratization" etc. All these processes are obviously much more variable than has been assumed by Max Weber and others. And if it is true that in Max Weber's writings one can find at least 16 different meanings of the word "rational" and thus at least 16 different meanings of "rationalization" [Brubaker 1984: 2], then one might ask how many processual terms remain intact at all, or can at least be used and applied in a meaningful way. One should take that question seriously and not fall into the trap of the somewhat facile counter-argument, namely that the sociological classics - and Weber in the first place - had only ideal-types in mind, talked only about ideal-typical processes [Bühl 2003: 146ff]. This is certainly true but doesn't solve the problem because sociologists without much ado rather quickly turn ideal-types into real-types. Exactly this was, early on, highlighted at the paradigmatic edges of historical sociology by authors such as Andrew Abbott, currently probably the most brilliant

${ }^{23}$ Cf. again the studies on the theory of secularization by Starrett [2010] or Agrama [2010]. Even a close reading of the history of sociology makes it plausible to argue that a radical thesis of functional differentiation is empirically not valid since it was already Weber himself who has argued that not all value spheres do have the same degree of an autonomous structural logic [cf. Schwinn 2001: 422].

24 This was the early critique of Herbert Blumer [1960; 1990 (1956)] who didn't realize when he made this point that the concept of the "industrial revolution" would later come under heavy fire. 
methodologist of sociology [see, for example, Abbott 2002]. In two articles already published in 1983 and 1984, he questioned the seemingly self-evident premises of the models of event-sequences so frequently used within (historical) sociology, asked how processes can be narrated at all, reflected upon the problem of appropriate units to be used in models of social processes, and tried to find out what happens if social orders with different temporalities interact [Abott 1983; 1984]. The whole problematique has not been much discussed in the subsequent period, however. And this is true with respect to historical sociology and social history because otherwise Jürgen Osterhammel's almost desperate plea (in his 2006 article mentioned above) for the search of more "fine-grained process terms" and for the thorough analysis of processual concepts such as "cycles", "repetitive structures", "path dependency", "mechanisms" would have been superfluous [Osterhammel 2006: 98 ff:; trans. W. K.].

Two brief remarks in this context: I believe that some of the terms evoked by Osterhammel in 2006 have in the meantime disappointed the high hopes which they originally had aroused: Here I refer mainly to "path dependency" and "mechanisms". With respect to the latter one has probably to say that at least within sociology the fashionable recent talk of "mechanisms" meets with growing scepticism, because it remains quite unclear how "mechanisms" found in the real world (and thus in specific cultural and temporal contexts) could be generalized at all. ${ }^{25}$ Such a belief in generalizability would only be justified if one assumes the repeatability of situations and especially continuously purposive-rational behaviour of the actors involved. But such assumptions - I think - are not common-sensical among historians. - With respect to "path dependency" a different problem arises, one using a reversal of a phrase used by Osterhammel - to be described this way: Osterhammel calls the theorem of "path dependency" a "Trojan Horse" which had been introduced into the rather ahistorical science of economics in order to smuggle in a "minimum of historical thinking" [Osterhammel 2006: 99; trans. W. K.]. However, one could also claim that the enthusiasm for "path dependency" in the neighboring disciplines of economics distracts from what these historically oriented disciplines currently need, namely a greater awareness and sensitivity to the analysis of different processes! It is undoubtedly true that the theorem of "path dependency" deals with events and thus assumes the possibility of a sudden breakdown of structures so that the much-criticized structural determinism of the systematic social sciences seems to be left behind. This, however, is not the whole story, because theoretical descriptions of historical reality based on this theorem use a strange dual ontology: On the one hand there is the ontology of the unique and contingent event (which triggers a process), on the other hand there is the ontology of long-lasting, stable, and anything but contingent process structures, i. e. the ontology of trajectories. ${ }^{26}$ Summing it all up one can claim that Osterhammel's diagnosis regarding the lack of a thematization of temporality is still valid. If one wants to correct this neglect, then - and here I come back to the first point of this section - studies such as Andrew Abbott's The System of Professions are more interesting and inspiring than Bourdieu's The Rules of Art.

Cultural historians have accused both social history and a historically oriented social science in general of a rather rigid adherence to the methodology of comparison, and thus

${ }^{25}$ Cf. the somewhat ambivalent attitude in Mayntz [2009: chaps. 5 and 6].

26 This is the critique of Steinmetz [2005: 144ff.]. 
to a meanwhile rather obsolete understanding of scientific "explanation". Of course, the defendants were not prepared to confess. But with respect to comparative methods one at least must admit that social historians and social scientists indeed have been listening and now acknowledge the methodological problems created by the undeniable existence of cultural transfers [Kocka 2002: 37]. Thus the once heated debate on this topic has somewhat lost momentum. - The situation is more complex with respect to the problem of "explanation" and "causality", however, since the arguments used are often based on shaky premises. The argument I would like to make is that a "will to explain" certainly can and should not be used as a criterion to distinguish social from cultural history - a point often misunderstood! To get things right, it is worth mentioning at least two observations related to each other: First, it is wrong to claim that the category of causality - which, for example, has been denounced as an "old European" concept by Niklas Luhmann - is really obsolete. It was certainly not Luhmann alone who tried to get rid of it; an early attempt can already be seen in the work of Ernst Cassirer (one of the reference authors of cultural historians, by the way!), namely in his Substanzbegriff und Funktionsbegriff [2000 (1910): 334ff.], a book Luhmann [1991: 72] positively referred to when discussing the concept of causality. Cassirer wanted to replace the term "causality" with the term "function" - and here he was in good company at least with some of his contemporaries: It was Bertrand Russell who predicted that science would increasingly abandon the concept of cause and deal instead with functional correlations. Russell's prediction was based on the assumption that causal statements are always nomological claims as well, i.e. he believed that talking of "causality" would logically require recourse to law-like statements. - But this was indeed a very specific and rather narrow understanding of "causality" as can be seen particularly in current debates within Anglo-American (not really "old European"!) philosophy in which in recent years an amazing return of the category of "causality" has been observed. ${ }^{27}$ There the link between laws on the one side and "causality" and "explanation" on the other is not considered self-evident at all, and explanation is considered as possible without general laws (something long ago argued forcefully by Max Weber). If that is so, then social history indeed would do well not to give up its search for causal explanation. The question, of course, is how "explanation" then has to be understood. And this is a serious question, to be sure! Whatever the answer will be, however, it should be clear that social historians (and historical sociologists as well, of course) should not be worried by accusations that themselves are based on a dubious concept of causal explanation. Second, Andrew Abbott, to return again to this important figure of historical sociology, has encouraged the social sciences to accept a broad understanding of explanation by distinguishing between syntactic, pragmatic and semantic statements [Abbott 2004: 3ff.]. For the historically-oriented disciplines primarily the syntactic and semantic models of explanations are important. Syntactic explanations ${ }^{28}$ build upon a meaning of causality as used in everyday language: Temporal relationships are created assuming that the earlier event causes the later phenomenon. This is the case in the famous Hempel-Oppenheim scheme and - albeit at a much less abstract level - in historical narratives. Such a syntactic model of explanation

27 Cf. the brilliant book by Keil [2000: 3].

28 The explanation is called "syntactic" by Abbott [2004: 12; emphasis in the original, W.K.] because it "emphasizes the syntax of an account rather than its ability to help us act (the pragmatic view) or its ability to translate a phenomenon into a realm we think we understand intuitively (the semantic view)." 
is mostly very elegant; it usually focuses "on the logical pattern of an account, on the way its parts are put together" [2004: 12]. But obviously not everybody is satisfied with such a way to explain. And here semantic explanations could come in. They translate and make a phenomenon plausible by reference to another one. Such a type of explanation is typical - on a very concrete level - for ethnographic accounts, as an example from sociology shows: In Distinction Bourdieu tries to demonstrate that differences in taste in reality only express differences in social class. Note that this translation process and thus the semantic explanation is made and achieved at the price that such statements are usually very static. But it is a reasonably explanation nevertheless; one, however, that obviously differs massively from a syntactic model. - Abbott's (and my) point here is that historical sociology as well as social history should be tolerant with respect to each type of explanation. It would not be wise to insist on only one explanatory model, precisely because each model has its shortcomings. This insight should help to see the once so heated discussion between social and cultural history in a somewhat calmer light (which is perhaps already happening anyway) and to oblige both parties to clarify what they exactly do when they give accounts, when they explain. In addition, Abbott's claim about a plurality of types of explanation should be the starting point to reflect upon the question whether after all these "turns" within the humanities (and the "cultural" turn is only one among many others) a really new epistemological situation has emerged. If one takes Abbott's position seriously, then there are some good reasons to doubt that! It is not that the epistemological situation has changed, it is more that we still often lack the theoretical means to understand a complex situation.

\section{Bibliography}

Abbott, Andrew. [1983]. Sequences of Social Events: Concepts and Methods for the Analysis of Order in Social Processes. Historical Methods 16 (4), pp. 129-147.

Abbott, Andrew. [1984]. Event Sequence and Event Duration: Colligation and Measurement. Historical Methods 17 (4), pp. 192-204.

Abbott, Andrew. [1988]. The System of Professions. An Essay on the Division of Expert Labor. Chicago \& London: University of Chicago Press.

Abbott, Andrew. [1991]. History and Sociology: The Lost Synthesis. Social Science History 15 (2), pp. 201-238.

Abbott, Andrew. [2002]. Time Matters. On Theory and Method. Chicago \& London: University of Chicago Press.

Abbott, Andrew. [2004]. Methods of Discovery. Heuristics for the Social Sciences. New York \& London: W. W. Norton \& Company.

Abbott, Andrew. [2006]. A Brief Note on Pasturization. International Journal of Comparative Sociology 47 (5), pp. 343-349.

Adams, Julia - Clemens, Elisabeth S. - Orloff, Ann Shola (eds.). [2005]. Remaking Modernity. Politics, History, and Sociology. Durham \& London: Duke UP.

Adams, Julia - Clemens, Elisabeth S. - Orloff, Ann Shola. [2005a]. Introduction: Social Theory, Modernity, and the Three Waves of Historical Sociology. In. Adams, Julia - Clemens, Elisabeth S. - Orloff, Ann Shola. Remaking Modernity. Politics, History, and Sociology. Durham \& London: Duke UP, pp. 1-72.

Agrama, Hussein Ali. [2010]. Secularism, Sovereignty, Indeterminacy: Is Egypt a Secular or a Religious State? Comparative Studies in Society and History 52 (3), pp. 495-523. 
Amenta, Edwin. [2003]. What we know about the Development of Social Policy. Comparative and Historical Research in Comparative and Historical Perspective. In. Mahoney, James - Rueschemeyer, Dietrich. Comparative Historical Analysis in the Social Sciences. Cambridge: Cambridge UP, pp. 91-130.

Asad, Talal. [2003]. Formations of the Secular. Christianity, Islam, Modernity. Stanford: Stanford UP.

Baldwin, Peter. [1990]. The Politics of Social Solidarity: Class Bases of the European Welfare State 1875-1975. Cambridge: Cambridge UP.

Barkey, Karen. [2008]. Empire of Difference. The Ottomans in Comparative Perspective. Cambridge: Cambridge UP.

Bensel, Richard. [1990]. Yankee Leviathan. The Origins of Central State Authority in America, 1859-1877. Cambridge. Cambridge UP.

Biernacki, Richard. [2005]. The Action Turn? Comparative-Historical Inquiry beyond the Classical Models of Conduct. In. Adams, Julia - Clemens, Elisabeth S. - Orloff, Ann Shola. Remaking Modernity. Politics, History, and Sociology. Durham \& London: Duke UP, pp. 75-91.

Blumer, Herbert. [1960]. Early industrialization and the labouring class. Sociological Quarterly 1 (1), pp. 5-14.

Blumer, Herbert. [1990 (1956)]. Industrialization as an Agent of Social Change. A Critical Analysis. Hawthorne: Aldine de Gruyter.

Boltanski, Luc. [1982]. Le Cadres. La formation d'un groupe social. Paris: Minuit.

Boltanski, Luc. [2010]. Soziologie und Sozialkritik. Frankfurter Adorno-Vorlesungen 2008. Frankfurt/Main: Suhrkamp.

Brubaker, Rogers. [1984]. The Limits of Rationality. An Essay on the Social and Moral Thought of Max Weber. London: Allen \& Unwin.

Bühl, Walter L. [2003]. Historische Soziologie - Theoreme und Methoden. Münster, Hamburg, London: LIT.

Burawoy, Michael. [1989]. Two methods in search of science. Skocpol versus Trotsky. Theory and Society 18 (6), pp. 759-805.

Calhoun, Craig. [1996]. The Rise and Domestication of Historical Sociology. In. McDonald, Terrence J. The Historic Turn in the Human Sciences. Ann Arbor: University of Michigan Press, pp. 305-337.

Cassirer, Ernst. [2000 (1910)]. Substanzbegriff und Funktionsbegriff. Gesammelte Werke - Hamburger Ausgabe. Band 6. Hamburg: Wissenschaftliche Buchgesellschaft.

Centeno, Miguel A. [2002]. Blood and Debt. War and the Nation-State in Latin-America. Pennsylvania: Pennsylvania State UP.

Collier, Ruth Berins. [1999]. Paths Toward Democracy. The Working Class and Elites in Western Europe and South America. Cambridge: Cambridge UP.

Collins, Randall. [1986]. Weberian Sociological Theory. Cambridge: Cambridge UP.

Daniel, Ute. [2010 (1993)]. ,Kultur' und ,Gesellschaft'. Überlegungen zum Gegenstandsbereich der Sozialgeschichte. In: Hitzer, Bettina - Welskopp, Thomas. Die Bielefelder Sozialgeschichte. Klassische Texte zu einem geschichtswissenschaftlichen Programm und seinen Kontroversen, Bielefeld: transcript, pp. 393-426.

Davis, Diane E. [2004]. Discipline and Development. Middle Classes and Prosperity in East Asia and Latin America. Cambridge: Cambridge UP.

Downing, Brian M. [1992]. The Military Revolution and Political Change. Origins of Democracy and Autocracy in Early Modern Europe. Princeton: Princeton UP.

Ertman, Thomas. [1997]. Birth of the Leviathan. Building States and Regimes in Medieval and Early Modern Europe. Cambridge: Cambridge UP.

Esping-Andersen, Gosta. [1990]. The Three Worlds of Welfare Capitalism. Princeton: Princeton UP.

Evans, Peter. [1995]. Embedded Autonomy. States and Industrial Transformation. Princeton: Princeton UP.

Evans, Peter - Rueschemeyer, Dietrich - Skocpol, Theda (eds.) [1985]. Bringing the State Back In. Cambridge: Cambridge UP.

Frevert, Ute. [1995 (1991)]. Men of Honour: A Social and Cultural History of the Duel. London: Polity Press. Giddens, Anthony. [1984]. The Constitution of Society. Outline of the Theory of Structuration. Cambridge: Polity Press.

Giddens, Anthony. [1985]. The Nation-State and Violence. Volume Two of A Contemporary Critique of Historical Materialism. Cambridge: Polity Press. 
Goldstone, Jack A. [1991]. Revolution and Rebellion in the Early Modern World. Berkeley/Los Angeles/ London: University of California Press.

Goldstone, Jack A. [2003]. Comparative Historical Analysis and Knowledge Accumulation in the Study of Revolutions. In. Mahoney, James - Rueschemeyer, Dietrich. Comparative Historical Analysis in the Social Sciences. Cambridge: Cambridge UP, pp. 41-90.

Goodwin, Jeff. [2001]. No Other Way Out. States and Revolutionary Movements, 1945-1991. Cambridge: Cambridge UP.

Gorski, Philip S. [2003]. The Disciplinary Revolution. Calvinism and the Rise of the State in Early Modern Europe. Chicago und London: University of Chicago Press.

Gorski, Philip S. [2006]. Mann's theory of ideological power: sources, applications and elaborations. In. Hall, John A. - Schroeder, Ralph. An Anatomy of Power. The Social Theory of Michael Mann. Cambridge: Cambridge UP, pp. 101-134.

Gourevitch, Peter. [1986]. Politics in Hard Times. Comparative Responses to International Economic Crises. Ithaca \& London: Cornell UP.

Grießinger, Andreas. [1981]. Das symbolische Kapital der Ehre. Streikbewegungen und kollektives Bewusstsein deutscher Handwerksgesellen im 18. Jahrhundert. Frankfurt/Main et al.: Ullstein.

Hall, John A. [1985]. Powers and Liberties. The Causes and Consequences of the Rise of the West. London: Penguin.

Hall, John A. [1989]. They do things differently there, or, the contribution of British Historical Sociology. British Journal of Sociology 40 (4), pp. 544-564.

Hall, Peter A. [1986]. Governing the Economy: The Politics of State Intervention in Britain and France. New York: Oxford UP.

Hicks. Alexander. [1999]. Social Democracy and Welfare Capitalism. A Century of Income Security Politics. Ithaca \& London: Cornell UP.

Honneth, Axel. [1995 (1992)]. The Struggle for Recognition. The Moral Grammar of Social Conflicts. Transl. by Joel Anderson. Cambridge: Polity Press.

Hunt, Lynn. [1984]. Culture, and Class in the French Revolution. Berkeley \& Los Angeles: University of California Press.

Ikegami, Eiko. [1995]. The Taming of the Samurai. Honorific Individualism and the Making of Modern Japan. Cambridge \& London: Harvard UP.

Joas, Hans. [1996 (1992)]. The Creativity of Action. Translated by Jeremy Gaines and Paul Keast. Chicago: University of Chicago Press.

Joas, Hans. [2003]. The Modernity of War: Modernization Theory and the Problem of Violence. In. Joas, Hans, War and Modernity. Cambridge: Polity, pp. 43-54.

Keil, Hartmut. [2000]. Handeln und Verursachen. Frankfurt/Main: Klostermann.

Kaelble, Hartmut - Jürgen Schriewer (eds.) [2003]. Vergleich und Transfer. Komparatistik in den Sozial-, Geschichts- und Kulturwissenschaften. Frankfurt/Main \& New York: Campus.

Kocka, Jürgen. [1972]. Otto Hintze. In. Wehler, Hans-Ulrich. Deutsche Historiker. Band III. Göttingen: Vandenhoeck \& Ruprecht, pp. 41-64.

Kocka, Jürgen. [1981]. Otto Hintze, Max Weber und das Problem der Bürokratie. Historische Zeitschrift 233, pp. 65-105.

Kocka, Jürgen. [2002]. Sozialgeschichte in Deutschland seit 1945. Aufstieg - Krise - Perspektiven. Vortrag auf der Festveranstaltung zum 40-jährigen Bestehen des Instituts für Sozialgeschichte am 25. Oktober 2002 in Braunschweig. Bonn: Friedrich-Ebert-Stiftung. Historisches Forschungszentrum.

Kohli, Atul. [1987]. The state and poverty in India. The politics of reform. Cambridge: Cambridge UP.

Laak, Dirk van. [2001]. Infra-Strukturgeschichte. Geschichte und Gesellschaft 27 (3), pp. 367-393.

Laak, Dirk van. [2004]. Imperiale Infrastruktur. Deutsche Planungen für eine Erschließung Afrikas 1880-1960. Paderborn et al.: F. Schöningh.

Laak, Dirk van. [2008]. Planung. Geschichte und Gegenwart des Vorgriffs auf die Zukunft. Geschichte und Gesellschaft 34 (3), pp. 305-326.

Lamont, Michèle. [1992]. Money, Morals \& Manner. The Culture of the French and the American Upper-Middle Class. Chicago \& London: University of Chicago Press.

Lange, Matthew. [2009]. Despotism and Development. British Colonialism and State Power. Chicago \& London: University of Chicago Press. 
Lange, Matthew - Rueschemeyer, Dietrich (eds.) [2005]. States and Development. Historical Antecedents of Stagnation and Advance. Basingstoke: Palgrave/Macmillan.

Lenger, Friedrich. [2010]. ,Historische Sozialwissenschaft': Aufbruch oder Sackgasse. In. Cornelißen, Christoph. Geschichtswissenschaft im Geist der Demokratie. Wolfgang J. Mommsen und seine Generation. Berlin: Akademie Verlag, pp. 115-132.

Lorenz, Chris. [2004]. Wozu noch Theorie der Geschichte? Über das ambivalente Verhältnis zwischen Gesellschaftsgeschichte und Modernisierungstheorie. In. Lorenz, Chris, Wozu Geschichte? Geschichtswissenschaft und Geschichtsphilosophie im Widerstreit. Stuttgart: Steiner, pp. 117-143.

Luhmann, Niklas. [1991]. Soziologische Aufklärung. In. Soziologische Aufklärung 1. Aufsätze zur Theorie sozialer Systeme. Opladen: Westdeutscher Verlag.

Mahoney, James. [2001]. The Legacies of Liberalism. Path Dependence and Political Regimes in Central America. Baltimore \& London: Johns Hopkins UP.

Mahoney, James. [2010]. Colonialism and Postcolonial Development. Spanish America in Comparative Perspective. Cambridge: Cambridge UP.

Mann, Michael. [2006]. The sources of social power revisited: a response to criticism. In. Hall, John A. Schroeder, Ralph. An Anatomy of Power. The Social Theory of Michael Mann. Cambridge: Cambridge UP, pp. 343-396.

Mann, Michael. [1986; 1993; 2012]. The Sources of Social Power. 3 Vols. Cambridge: Cambridge UP.

Mayntz, Renate. [2009]. Sozialwissenschaftliches Erklären. Probleme einer Theoriebildung und Methodologie. Frankfurt/Main \& New York: Campus.

Moore, Barrington, Jr. [1966]. Social Origins of Dictatorship and Democracy. Lord and Peasant in the Making of the Modern World. Boston: Beacon Press.

Moore, Barrington, Jr. [1978]. Injustice. The Social Bases of Obedience and Revolt. London \& Basingstoke: Macmillan.

Moore, Barrington, Jr. [1984]. Privacy. Studies in Social and Cultural History. Armonk \& London: M. E. Sharpe.

Orloff, Ann Shola. [1993]. The Politics of Pensions: A Comparative Analysis of Britain, Canada, and the United States, 1880-1940. Madison: University of Wisconsin Press.

Osterhammel, Jürgen. [2006]. Gesellschaftsgeschichte und Historische Soziologie. In. Osterhammel, Jürgen - Langewiesche, Dieter - Nolte, Paul. Wege der Gesellschaftsgeschichte. Göttingen: Vandenhoeck \& Ruprecht, pp. 81-102.

Page, Edward C. [1990]. The Political Origins of Self-Government and Bureaucracy: Otto Hintze's Conceptual Map of Europe. Political Studies 38 (1), pp. 39-55.

Paige, Jeffrey M. [1997]. Coffee and Power. Revolution and the Rise of Democracy in Central America. Cambridge, Mass. \& London: Harvard UP.

Parsa, Misagh. [2000]. States, Ideologies, and Social Revolutions. Cambridge: Cambridge UP.

Pierson, Paul [1994]. Dismantling the Welfare State? Reagan, Thatcher, and the Politics of Retrenchment. Cambridge: Cambridge UP.

Ragin, Charles C. [1987]. The Comparative Method. Moving Beyond Qualitative and Quantitative Strategies. Berkeley, Los Angeles \& London: University of California Press.

Ragin, Charles. [2000]. Fuzzy-Set Social Science. Chicago \& London: University of Chicago Press.

Roth, Guenther. [1989]. Vergangenheit und Zukunft der historischen Soziologie. Weiß, Johannes. Max Weber heute: Erträge und Probleme der Forschung. Frankfurt/Main: Suhrkamp, pp. 406-424.

Rueschemeyer, Dietrich. [2009]. Usable Theory. Analytic Tools for Social and Political Research. Princeton \& Oxford: Princeton UP.

Rueschemeyer, Dietrich - Huber Stephens, Evelyne - Stephens, John D. (eds.) [1992]. Capitalist Development and Democracy. Cambridge: Polity Press.

Schwinn, Thomas. [2001]. Differenzierung ohne Gesellschaft. Umstellung eines soziologischen Konzepts. Velbrück: Velbrück Wissenschaft.

Sewell, William H., Jr. [1994]. Ideologies and social revolutions: Reflections on the French case. In. Skocpol, Theda. Social Revolutions in the Modern World. Cambridge: Cambridge UP, pp. 169-198.

Sewell, William H., Jr. [2005]. Logics of History. Social Theory and Social Transformation. Chicago \& London: University of Chicago Press. 
Sheehan, James J. [1980]. Barrington Moore on Obedience and Revolt. Theory and Society 9 (5), pp. 723-734.

Skocpol, Theda. [1979]. States and Social Revolutions. A Comparative Analysis of France, Russia \& China. Cambridge: Cambridge UP.

Skocpol, Theda. [1987]. Social History and Historical Sociology: Contrasts and Complementarities. Social Science History 11 (1), pp. 17-30.

Skocpol, Theda. [1992]. Protecting Soldiers and Mothers. Cambridge, Mass.: The Belknap Press.

Skocpol, Theda. [1994a]. Social Revolutions in the Modern World. Cambridge: Cambridge UP.

Skocpol, Theda. [1994b]. A Critical review of Barrington Moore's Social Origins of Dictatorship and Democracy. In. Skocpol, Theda. Social Revolutions in the Modern World. Cambridge: Cambridge UP, pp. 25-54.

Skocpol, Theda. [1994c]. Cultural idioms and political ideologies in the revolutionary reconstruction of state power: A rejoinder to Sewell. In. Skocpol, Theda. Social Revolutions in the Modern World. Cambridge: Cambridge UP, pp. 199-209.

Skowronek, Stephen. [1982]. Building a New American State. The Expansion of National Administrative Capacities, 1877-1920. Cambridge: Cambridge UP.

Soifer, Hillel. [2008]. State Infrastructural Power: Approaches to Conceptualization and Measurement. Studies in Comparative International Development 43 (3/4), pp. 231-251.

Soifer, Hillel - Hau, Matthias vom. [2008]. Unpacking the Strength of the State: The Utility of State Infrastructural Power. Studies in Comparative International Development 43 (3/4), pp. 219-230.

Spohn, Willfried. [1989]. Zum methodologischen Verhältnis von Sozialgeschichte, historischer Soziologie und Geschichtsphilosophie am Beispiel einiger jüngerer Interpretationsansätze der Klassenformierung der Arbeiterschaft. Archiv für Kulturgeschichte 71 (2), pp. 487-501.

Starrett, Gregory. [2010]. The Varieties of Secular Experience. Comparative Studies in Society and History $52(3)$, pp. 626-651.

Steinmetz, George (ed.) [1999]. State/Culture. State-Formation after the Cultural Turn. Ithaca \& London: Cornell UP.

Steinmetz, George. [2005]. The Epistemological Unconsciousness of U.S. Sociology and the Transition to Post-Fordism: The Case of Historical Sociology. In. Adams, Julia - Clemens, Elisabeth S. - Orloff, Ann Shola. Remaking Modernity. Politics, History, and Sociology. Durham \& London: Duke UP, pp. 109-157

Tenbruck, Friedrich. [1981]. Emile Durkheim oder die Geburt der Gesellschaft aus dem Geiste der Soziologie. Zeitschrift für Soziologie 10, pp. 333-350.

Tenbruck, Friedrich. [1994]. Internal History of Society or Universal History? Theory, Culture \& Society 11 (1), pp. 75-93.

Tenfelde, Klaus. [1980]. German Workers and the Incapacity for Revolution. Theory and Society 9 (5), pp. 735-744.

Terpe, Sylvia. [2009]. Ungerechtigkeit und Duldung. Die Deutung sozialer Ungleichheit und das Ausbleiben von Protest. Konstanz: UVK.

Tilly, Charles. [1986]. The Contentious French. Four Centuries of Popular Struggle. Cambridge, Mass. \& London: The Belknap Press of Harvard UP.

Tilly, Charles. [1990]. Coercion, Capital, and European States, A.D. 990-1990. Cambridge: Cambridge UP. Tilly, Charles. [1978]. From Mobilization to Revolution. New York et al.: McGraw-Hill.

Tilly, Charles - Tilly, Louise - Tilly, Richard. [1975]. The Rebellious Century 1830-1930. Cambridge, Mass: Harvard UP.

Touraine, Alain. [1981]. Une sociologie sans société. Revue française de Sociologie 22 (1), pp. 3-13.

Wehler, Hans-Ulrich. [1975]. Modernisierungstheorie und Geschichte. Göttingen: Vandenhoeck \& Ruprecht. Wehler, Hans-Ulrich. [1985 (1973)]. The German Empire, 1871-1918. Oxford \& New York: Berg Publishers. Wehler, Hans-Ulrich. [2000]. Modernisierung und Modernisierungstheorien. In. Wehler, Hans-Ulrich. Umbruch und Kontinuität. Essays zum 20. Jahrhundert. München: C. H. Beck, pp. 214-250.

Wehler, Hans-Ulrich. [2010 (1988)]. Historische Sozialwissenschaft. Eine Zwischenbilanz nach dreißig Jahren. In. Hitzer, Bettina - Welskopp, Thomas. Die Bielefelder Sozialgeschichte. Klassische Texte zu einem geschichtswissenschaftlichen Programm und seinen Kontroversen. Bielefeld: transcript, pp. 433-441. 
Weiss, Linda [1998]. The Myth of the Powerless State. Ithaca \& New York: Cornell UP.

Welskopp, Thomas. [1998]. Die Sozialgeschichte der Väter. Grenzen und Perspektiven der Historischen Sozialwissenschaft. Geschichte und Gesellschaft 24, pp. 173-198.

Welskopp, Thomas. [1999]. Westbindung auf dem ,Sonderweg. Die deutsche Sozialgeschichte vom Appendix der Wirtschaftsgeschichte zur Historischen Sozialwissenschaft. In. Küttler, Wolfgang - Rüsen, Jörn - Schulin, Ernst. Geschichtsdiskurs. Band 5: Globale Konflikte, Erinnerungsarbeit und Neuorientierungen seit 1945, Frankfurt/Main: Fischer, pp. 191-237.

Wirtz, Rainer. [1981]. ,Widersetzlichkeiten, Excesse, Crawalle, Tumulte und Skandale. Soziale Bewegung und gewalthafter sozialer Protest in Baden 1815-1848. Frankfurt/Main et al.: Ullstein.

Zelizer, Viviana A. [1994]. The Social Meaning of Money. New York: Basic Books.

Ziemann, Benjamin.[2003]. Sozialgeschichte jenseits des Produktionsparadigmas. Überlegungen zu Geschichte und Perspektive eines Forschungsfeldes. Mitteilungsblatt des Instituts für soziale Bewegungen 28, pp. 5-35.

Wolfgang Knöbl, Professor of Sociology at the Georg-August University Göttingen, Germany. Research interests: Social Theory, history of sociology, political sociology, comparative-historical sociology. Most recent books: Die Kontingenz der Moderne. Wege in Europa, Asien und Amerika (2007); with Hans Joas: Social Theory. Twenty Introductory Lectures. (Cambridge 2009); with Hans Joas: War in Social Thought. Hobbes to the Present (Princeton UP, 2012). 